\title{
THE EFFECT OF TEMPERATURE ON MOBILITY OF Angiostrongylus costaricensis' THIRD STAGE LARVAE
}

Lúcia M.Z. RICHINITTI(1,3), Nivaldo A. FOnSECA(2) \& Carlos GRAEFF-TEIXEIRA(1)

\begin{abstract}
SUMMARY
Third stage larvae (L3) from Angiostrongylus costaricensis were incubated in water at room temperature and at $5{ }^{\circ} \mathrm{C}$ and their mobility was assessed daily for 17 days. Viability was associated with the mobility and position of the L3, and it was confirmed by inoculation per os in albino mice. The number of actively moving L3 sharply decreased within 3 to 4 days, but there were some infective L3 at end of observation. A mathematical model estimated 80 days as the time required to reduce the probability of infective larvae to zero. This data does not support the proposition of refrigerating vegetables and raw food as an isolated procedure for prophylaxis of human abdominal angiostrongylosis infection.
\end{abstract}

KEYWORDS: Angiostrongylus costaricensis; Food-born disease; Mollusca.

\section{INTRODUCTION}

Angiostrongylus costaricensis Morera and Céspedes, 1971 is a parasitic nematode of wild rodents that may produce abdominal disease in humans, already reported from most countries in the Americas, from Mexico to Argentina ${ }^{1}$. Molluscs are intermediate hosts and shed infective third stage larvae (L3) in their mucus secretions ${ }^{3}$.

One possible mode of infection is the ingestion of raw vegetables and unpeeled fruits containing small molluscs or their contaminated mucous secretions ${ }^{3}$. MORERA ${ }^{4}$ suggested refrigeration of food as part of prophylaxis based on experiments demonstrating a deleterious effect of low temperatures on the viability of L3.

The objective of these experiments is to analyse the effect of temperature on L3 motility and evaluate if refrigeration in prophylaxis of the human infection by Angiostrongylus costaricensis is applicable.

\section{MATERIAL AND METHODS}

The Santa Rosa strain of A. costaricensis has been maintained in the laboratory since 1992, through the infection of Mus musculus Swiss mice and the veronicelid slug, Phyllocaulis soleiformis. Groups of 135 L3 were isolated from slugs and incubated in tap water in a refrigerator $\left(5^{\circ} \mathrm{C}\right)$ and at room temperature for 17 days. Control groups of larvae were inoculated per os in mice ( $12 \mathrm{~L} 3 /$ animal, 6 mice per group) immediately after isolation from molluscs. The number of actively moving larvae was daily determined under a estereomicroscopy.
In preliminary experiments it was found that larvae kept in water gradually lost their motility, some immobile larvae reassume active movements particularly under gentle heating and those larvae standing in a "c" position would represent inviable, dying larvae (Fig. 1). In the present observations, larvae were classified as "active", "intermediate" or "inactive". The inviability of these inactive larvae was demonstrated in one group left in water at $5{ }^{\circ} \mathrm{C}$ for 29 days and inoculated into mice, without establishment of infection.

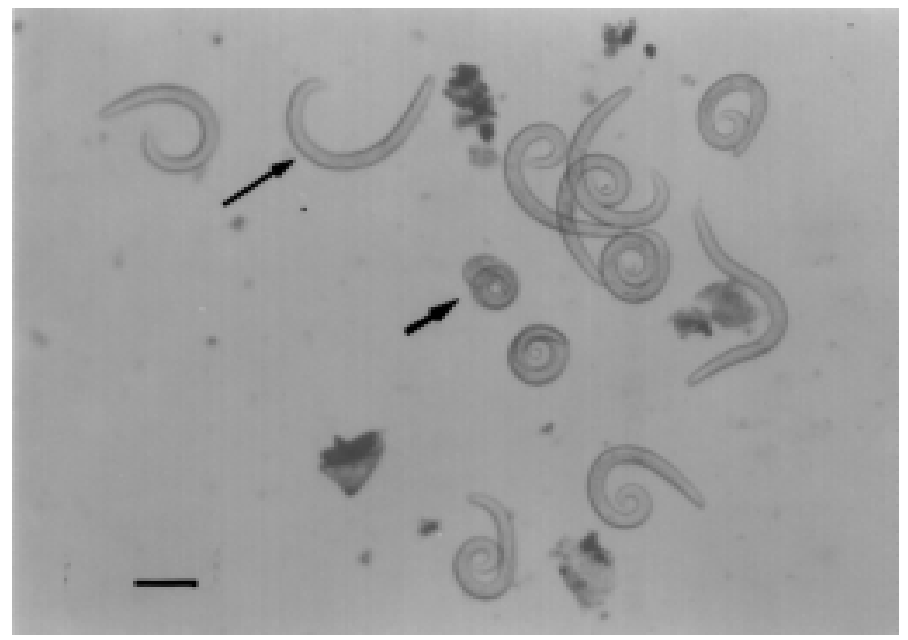

Fig. 1 - Illustration of larvae classified according to shape: tightly whorled "intermediate" L3 (short arrow) and "inactive" in "c" position (long arrow).

(1) Instituto de Biociências (Pós-Graduação) \& Instituto de Pesquisas Biomédicas, PUCRS, Porto Alegre, RS, Brasil.

(2) Instituto de Matemática, PUCRS, Porto Alegre, RS, Brasil.

(3) Museu de Ciências e Tecnologia, Pontifícia Universidade Católica do Rio Grande do Sul, PUCRS, 90619-900 Porto Alegre, RS, Brasil.

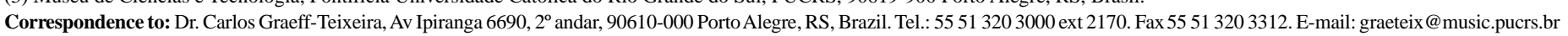


At the end of the observation period, the larvae were inoculated per os in mice that were killed after 28 days and examined for the presence of adult worms inside intra-abdominal blood vessels. This experiment was repeated four times.

The adequacy of mathematical models for expression of the kinetics of reduction of the number of active, intermediate or inactive larvae along time were analyzed through a test of adjustment of the angular coefficient by Student's $\mathbf{t}$ test and a choice for $\mathbf{f}(\mathbf{x})$ with lowest $\mathbf{p}$ value, lowest residual sd, highest single linear correlation and subjective analysis of coherence between the chosen model and the observational data. The $Z$ test $(\alpha=0.05$ and critic $\mathbf{z}=1.96)$ was employed for determination of significance in the difference between ratios of yield in experimental (RT and $5{ }^{\circ} \mathrm{C}$ ) and control groups.

\section{RESULTS}

There was a sharp decrease in the number of active larvae kept in RT and at $5{ }^{\circ} \mathrm{C}$ in the first 3 or 4 days (Fig. 2). A wider variation was observed among results obtained at RT, without a significant difference as demonstrated in the mathematical model. The number of "intermediate" larvae increased, producing a mirror pattern to the graph of active L3 (Fig. 3) and the number of "inactive" L3 varied widely along time, especially at RT (Fig. 4).
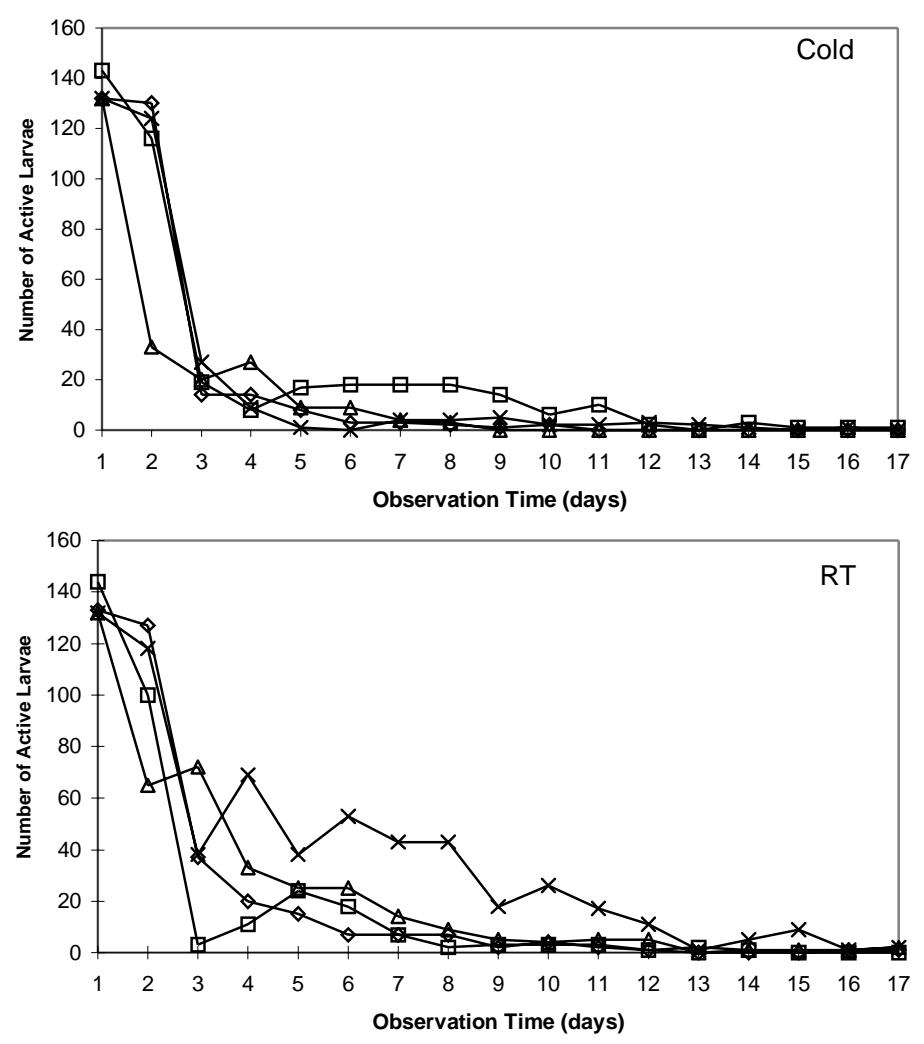

Fig. 2 - Counting of "active" larvae incubated in water, at $5{ }^{\circ} \mathrm{C}$ (Cold, upper graphic) or room temperature (RT) (lower graphic).
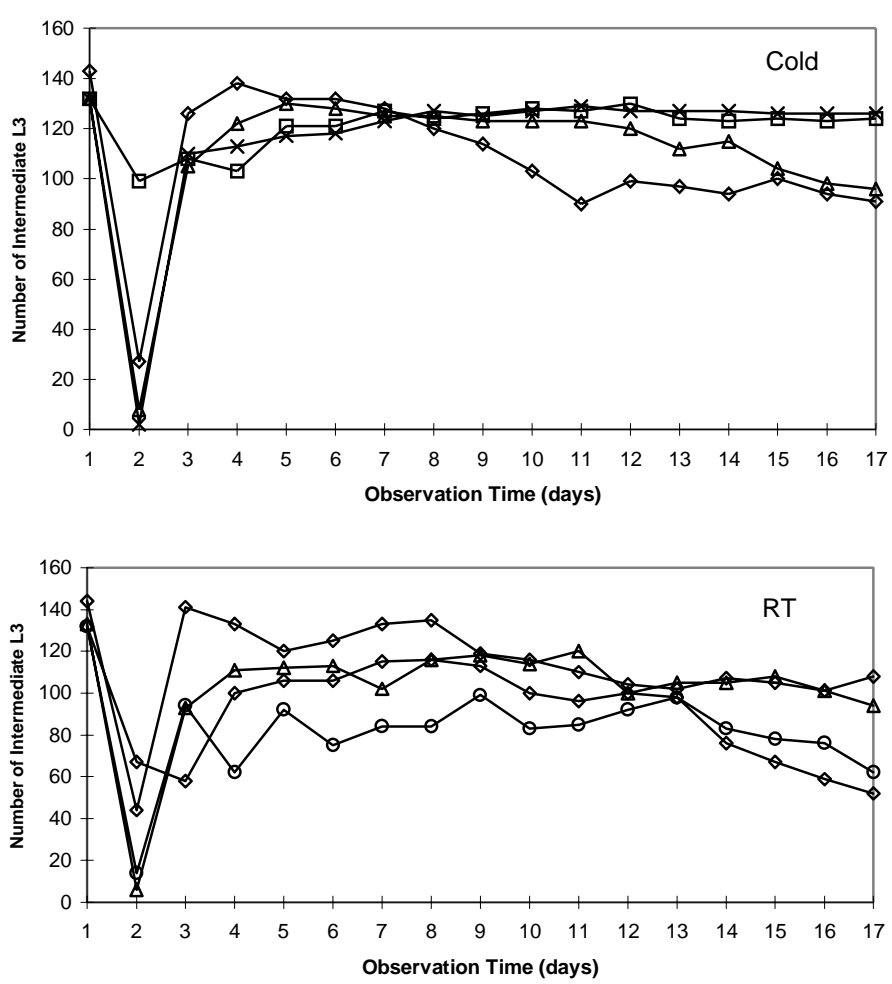

Fig. 3 - The same as in Fig. 1., for "intermediate" larvae.
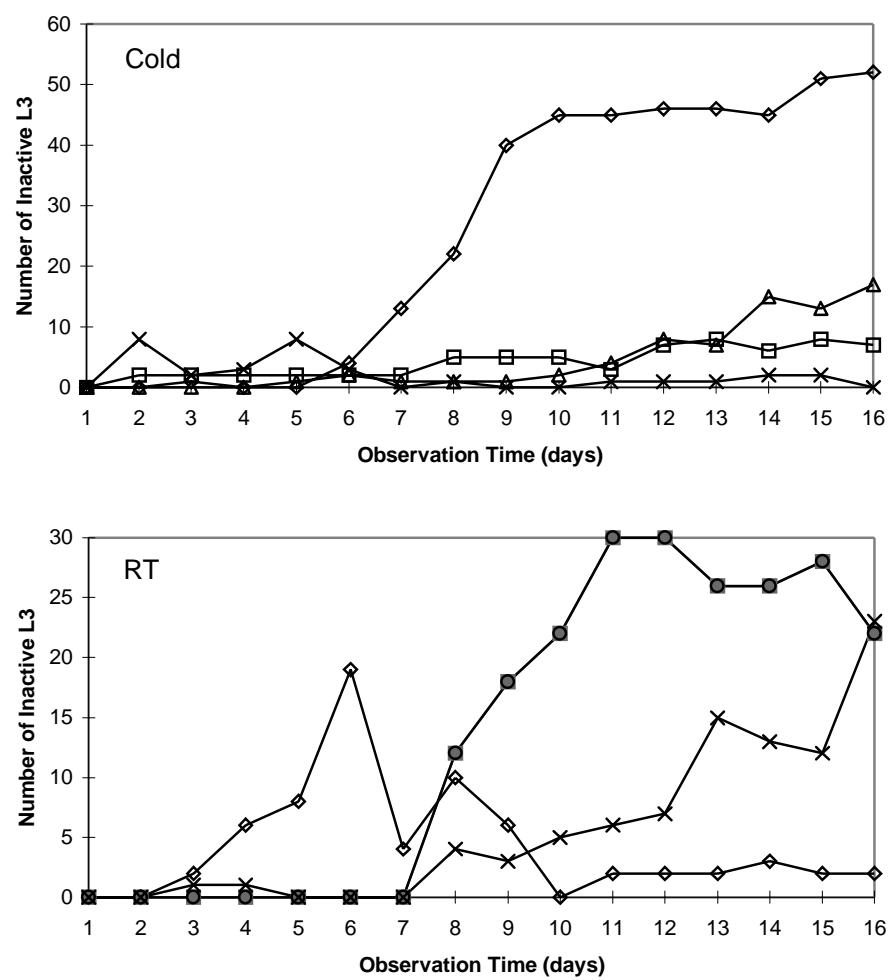

Fig. 4 - The same as in Fig. 1., for "inactive" larvae. 

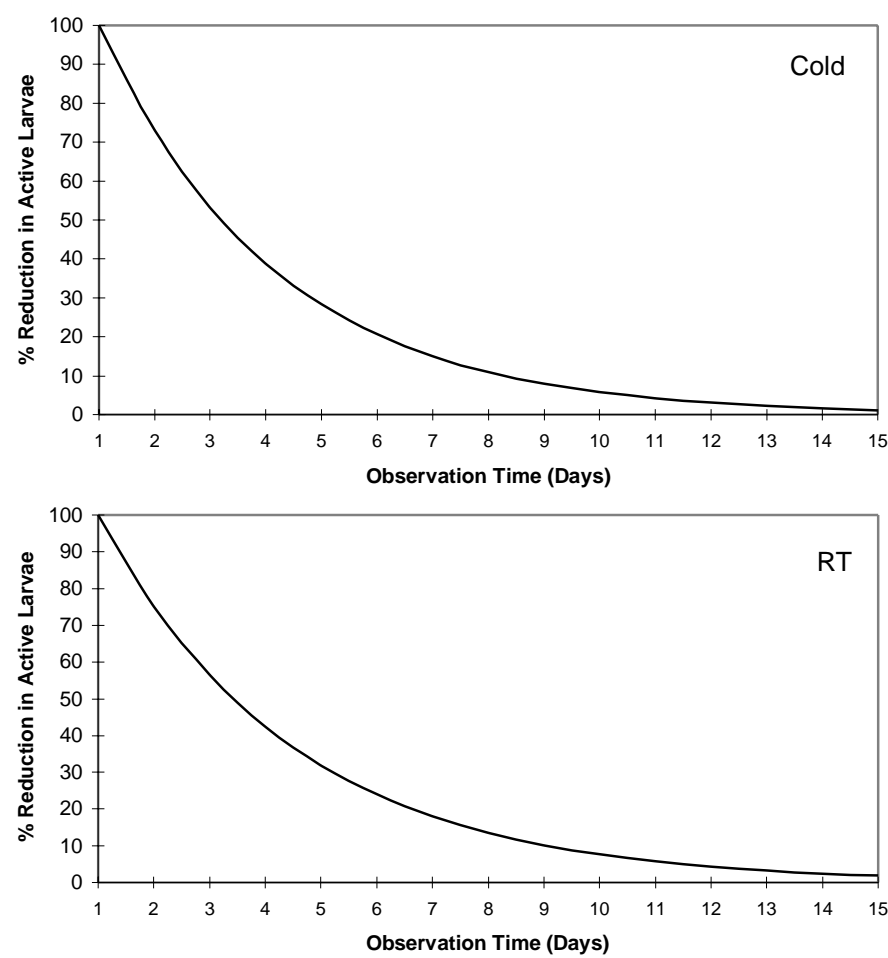

Fig. 5 - Graphics of the equations representing the reduction of "active" larvae, incubated at RT or at $5{ }^{\circ} \mathrm{C}$

Exponential functions represented by the equations

a) $Y=120.22 \times 0.729457^{x}$ for incubation at $5^{\circ} \mathrm{C}$ and

b) $Y=251.18 \times 0.7516^{x}$ for incubation at room temperature,

were found to be well adjusted to the experimental data, accurately representing the decreasing number of active larvae (Fig. 5). These models led to the estimate that 80 days is the minimum length of time required for reaching $100 \%$ reduction of active larvae.

The inoculation of larvae after 17 days of observation did not result in higher mortality than the control group (Table 1), but both the proportion of infected animals and the resultant total number of worms was significantly higher in the experimental groups. There was not a significant difference in the results of inoculation with larvae incubated at $5{ }^{\circ} \mathrm{C}$ or RT.

\section{DISCUSSION}

The experiments currently reported above show that the activity and position of $A$. costaricensis' larvae is related to its infectivity. Infection was not documented for open "c" larvae while actively moving and whorled larvae were usually infectious. Loss of infectivity is not guaranteed if larvae are in intermediate positions. This preliminary demonstration made possible the experimental approach for the description of the effect of low temperatures along time on larvae.

HORI et al. ${ }^{2}$ have demonstrated that the development from L1 to L3, of Angiostrongylus cantonensis larvae, was negatively effected by low temperatures, especially at $10{ }^{\circ} \mathrm{C}$ and MORERA ${ }^{4}$ has proposed the refrigeration of food as a prophylactic measure. The cold has also been proposed as one explanation for the seasonality in the occurrence of the human disease in southern Brazil, reducing the risk of transmission during the winter ${ }^{1}$.

Prophylaxis is the only possible intervention in the natural history of this nematode infection, since there is no efficient drug therapy available so far $^{5}$. Almost $100 \%$ of larvae can be inactivated by incubation in a $1.5 \%$ bleaching water solution (unpublished observations), which stands as a promising prophylactic intervention.

Although, both at RT and $5{ }^{\circ} \mathrm{C}$, there is a sharp reduction in the number of active larvae in 24 hours, next to $10 \%$ of active larvae can be found at days 9 or 10 . With the application of mathematical models, 80 days would be the estimated time to inactivate all larvae. This data confirms preliminary experiments showing that after 96 hours of incubation at $5{ }^{\circ} \mathrm{C}$ there were infective larvae $e^{8}$. In this setting, besides being impractical and probably not well-accepted by the population, the refrigeration of vegetables or other undercooked food for several days is not a fully efficacious prophylactic procedure.

In $75 \%$ of Phyllocaulis variegatus found naturally infected in southern Brazil, the individual parasitic burden was less than 10 L3 and only three animals had more than 20 larvae ${ }^{7}$. In experimental conditions the number of larvae found in the mucous secretions was always very low, even with high parasitic burdens ${ }^{6}$. We do not know the infective dosis for humans, but the data may be taken as an indication that few larvae can establish infection and produce disease. If this idea is confirmed we should look for highly effective prophylactic measures, which does not appear to be the case of the isolated use of low temperatures.

TABLE 1

Results of inoculation in Swiss mice of Angiostrongylus costaricensis' third stage larvae (L3) incubated for 17 days at $5^{\circ} \mathrm{C}$ or room temperature (RT). The control group was infected with 288 active L3 on the first day of observation, immediately after their isolation from the molluscs. Yield was estimated as a ration between the total number of worms and the total inoculate

\begin{tabular}{|c|c|c|c|c|c|c|c|c|c|}
\hline & \multirow[t]{2}{*}{ Mortality } & \multirow{2}{*}{$\begin{array}{l}\text { Infected/ } \\
\text { examined }\end{array}$} & \multicolumn{3}{|c|}{ L3 Inocula } & \multirow{2}{*}{$\begin{array}{c}\text { Total } \\
\text { Inocula }\end{array}$} & \multirow{2}{*}{$\begin{array}{c}\text { Total } \\
\text { Worms }\end{array}$} & \multirow[t]{2}{*}{ Yield } & \multirow{2}{*}{$\begin{array}{c}\text { estimated } \\
\text { " } z \text { " }\end{array}$} \\
\hline & & & Intermed & Inactive & Active & & & & \\
\hline Control & $1 / 24$ & $20 / 23$ & 0 & 0 & 288 & 288 & 78 & 0.270 & - \\
\hline $5^{\circ} \mathrm{C}$ & $0 / 19$ & $1 / 14$ & 267 & 72 & 0 & 339 & 1 & 0.003 & 10.14 \\
\hline RT & $0 / 17$ & $2 / 15$ & 238 & 85 & 13 & 336 & 6 & 0.018 & 9.28 \\
\hline
\end{tabular}




\section{RESUMO}

\section{O Efeito da temperatura na motilidade de larvas de terceiro estágio de Angiostrongylus costaricensis}

Larvas de terceiro estágio (L3) de Angiostrongylus costaricensis foram incubadas em água na temperatura ambiente e a $5{ }^{\circ} \mathrm{C}$, e a sua motilidade foi avaliada diariamente pelo período de 17 dias. Viabilidade esteve associada com a mobilidade e a posição da L3 e foi confirmada pela inoculação oral de camundongos albinos. O número de L3 movendo-se ativamente decresceu muito nos primeiros 3 a 4 dias, mas existiam algumas L3 infectantes no final do período de observação. Um modelo matemático estimou em 80 dias o tempo necessário para reduzir a probabilidade de infecção a zero. Estes dados não favorecem a proposta de refrigeração de verduras e outros alimentos consumidos crus, como um procedimento isolado para a profilaxia da angiostrongilose abdominal humana.

\section{ACKNOWLEDGEMENTS}

This project was supported by PUCRS, CAPES and CNPq. C. GraeffTeixeira is recipient of a CNPq PQ IIB fellowship (301076/91-0). We also thank Eva Medeiros for technical help.

\section{REFERENCES}

1. GRAEFF-TEIXEIRA, C.; CAMILLO-COURA, L. \& LENZI, H.L. - Clinical and epidemiological studies on abdominal angiostrongyliasis in southern Brazil. Rev. Inst. Med. trop. S.Paulo, 33: 375-380, 1991.
2. HORI, E.; YAMAGUCHI, K.; FUJIMOTO, K.; NISHINA, M. \& TAKAHASHI, M. Experimental studies on the development of Angiostrongylus cantonensis larvae in mollusks: development under low temperatures. Jap. J. Parasit., 34: 272-284, 1985.

3. MORERA, P. - Life history and redescription of Angiostrongylus costaricensis, Morera and Céspedes, 1971. Amer. J. trop. Med. Hyg., 22: 613-621, 1973.

4. MORERA, P. - Angiostrongiliasis abdominal: transmision y observaciones sobre su posible control. In: CONTROL Y ERRADICACIÓN DE ENFERMEDADES INFECCIOSAS: UN SIMPOSIO INTERNACIONAL. Washingtom, PAHO, 1985. (Pan Amer. Hlth. Org. Copublic. Ser., 1: 230-235, 1985).

5. MORERA, P. \& BONTEMPO, I. - Acción de algunos antihelminticos sobre Angiostrongylus costaricensis. Rev. Biol. trop. (S. Jose), 18: 173-185, 1985.

6. OLIVEIRA-BONETTI, V.C.B.D. \& GRAEFF-TEIXEIRA, C. - Angiostrongylus costaricensis and the intermediate hosts: observations on elimination of L3 in the mucus and inoculation of L1 through the tegument of molluscs. Rev. Soc. bras. Med. trop., 31: 289-294, 1998.

7. RAMBO, P.R.; AGOSTINI, A.A. \& GRAEFF-TEIXEIRA, C. - Abdominal angiostrongylosis in southern Brazil: prevalence and parasitic burden in mollusc intermediate hosts from eighteen endemic foci. Mem. Inst. Oswaldo Cruz, 92: 9$14,1998$.

8. RICHINITTI, L.M.Z. \& GRAEFF-TEIXEIRA, C. - Efeito da temperatura baixa sobre a viabilidade de larvas de terceiro estágio de Angiostrongylus costaricensis Morera \& Céspedes, 1971 (Nematoda, Angiostrongylidae). Biociências (P. Alegre), 5: 151154, 1997.

Received: 22 March 1999

Accepted: 01 July 1999 